\title{
JENIS MP-ASI, FREKUENSI DAN WAKTU PERTAMA KALI PEMBERIAN MP-ASI SEBAGAI FAKTOR RISIKO KEJADIAN GIZI LEBIH PADA BAYI USIA 6-12 BULAN DI KOTA MAGELANG
}

\author{
Vania Retno Nurastrini, Apoina Kartini ${ }^{*}$ \\ Program Studi Ilmu Gizi Fakultas Kedokteran Universitas Diponegoro \\ J1.Dr.Sutomo No.18, Semarang, Telp (024) 8453708, Email : gizifk@undip.ac.id
}

\begin{abstract}
Background: The prevalence of overweight at children under five in Magelang at 2012 based on the data in the health profile were 5.8\%. Giving complementary feeding to infants less than 4 months with high frequency and wrong types will cause weight gain too fast thus leading to overweight.

Methods: This study was conducted with the case-control design in 27 cases (overweight) and 27 controls (normal) with matching process, such as gender, formula milk consumption, and address. Nutritional status categorized by weight height zscore (WHZ) more than 2 SD according to the WHO child growth standards. The data that consist of length birth weight, birth weight, formula milk consumption, gender, type of complementary feeding, frequency of giving complementary feeding, and first time of complementary feeding on infants aged 6-12 months were obtained through interviews using a structured questionnaire. The analysis was performed with Chi-Square and OR.

Results: Type of complementary feeding was not appropriate in the age in case group was 55.6\%, whereas in the control group was $40.7 \%$. Case group who received complementary feeding more than 3 times a day was $96.3 \%$, whereas the control group was 59.3\%. Case group who received complementary feeding before 6 months of age was $66.7 \%$, whereas in the control group was $29.6 \%$.This study showed that the incidence of risk factors for overweight in infants 6-12 months is the frequency of complementary feeding $(p=0.002: O R=17.9)$ and the first time the provision of complementary feeding $(p=0.01:$ OR $=4.75)$. Type of complementary feeding is not a risk factor for the incidence of overweight in infants aged 6-12 months $(p=0.4: O R=0.55)$

Conclusion: Risk factors for the incidence of overweight in infants aged 6-12 months in Magelang are frequency of complementary feeding giving, first time of giving complementary feeding
\end{abstract}

Keywords: overweight; infants aged 6-12 months; complementary feeding

\section{ABSTRAK}

Latar Belakang:. Prevalensi anak balita gizi lebih di Kota Magelang tahun 2012 berdasarkan data di Profil Kesehatan Kota sebesar 5,8\% . Pemberian makanan pendamping ASI yang diberikan pada bayi kurang dari 4 bulan dengan frekuensi yang tinggi dan jenis yang tidak sesuai umur akan menyebabkan kenaikan berat badan yang terlalu cepat sehingga mengarah ke gizi lebih.

Metode: Penelitian ini dilakukan dengan rancangan kasus kontrol pada 27 gizi lebih sebagai kelompok kasus dan 27 gizi normal sebagai kelompok kontrol dengan disertai matching umur, jenis kelamin, konsumsi susu formula dan tempat tinggal. Kriteria gizi lebih ditentukan berdasarkan indeks z-score BB/PB >2 SD menurut WHO child growth standart. Data umur, panjang badan, berat badan, jenis kelamin, konsumsi susu formula, jenis MP-ASI, frekuensi pemberian MP-ASI, dan waktu pemberian MP-ASI pertama kali pada bayi usia 6-12 bulan diperoleh melalui wawancara menggunakan kuesioner terstruktur. Analisis dilakukan dengan Pearson Chi-Square dan OR.

Hasil: Pemberian MP-ASI yang tidak sesuai umur pada kelompok kasus sebesar 55,6\%, sedangkan pada kelompok kontrol sebesar 40,7\%. Kelompok kasus yang mendapat MP-ASI lebih dari 3 kali sehari sebesar 96,3\%, sedangkan pada kelompok kontrol sebesar 59,3\%. Kelompok kasus yang mendapat MP-ASI sebelum usia 6 bulan sebesar 66,7\%, sedangkan pada kelompok kontrol sebesar 29,6\%. Penelitian ini menunjukkan, faktor risiko kejadian gizi lebih pada bayi 6-12 bulan adalah frekuensi pemberian MP-ASI ( $p=0,002: 0 R=17,9)$ dan waktu pertama kali pemberian MP-ASI ( $p=0,01: O R=4,8)$. Pemberian MP-ASI yang tidak sesuai umur bukan merupakan faktor risiko kejadian gizi lebih pada bayi usia 6-12 bulan ( $p=0,4: O R=0,55)$

Simpulan: Faktor risiko kejadian gizi lebih pada bayi usia 6-12 bulan di Kota Magelang adalah frekuensi pemberian MP-ASI dan waktu pertama kali pemberian MP-ASI

Kata Kunci: gizi lebih; bayi usia 6-12 bulan; MP-ASI

\section{PENDAHULUAN}

Prevalensi anak gizi lebih di Amerika tahun 2009-2010 pada usia pra sekolah sebesar $12,1 \%$. Jumlah ini mengalami kenaikan pesat dibanding tahun 1975-1980 hanya sebesar 5\%. Sedangkan menurut NHANES, prevalensi gizi lebih pada anak dan remaja pada usia 2-19 tahun sebesar 16,9\% pada taun 2009-2010. Di Indonesia, 
prevalensi gizi lebih pada balita menurut SUSENAS menunjukkan peningkatan, baik di perkotaan maupun di pedesaan. Di perkotaan pada tahun 1989 didapatkan 4,6\% lelaki dan 5,9\% perempuan. Pada tahun 1992 didapatkan 6,3\% laki-laki dan $8 \%$ untuk perempuan. Kasus gizi lebih pada remaja lebih banyak ditemukan pada wanita $(10,2 \%)$ dibanding lelaki $(3,1 \%){ }^{1}$

Berdasarkan data Riskesdas 2010, prevalensi gizi lebih di Jawa Tengah pada balita sebesar $6,2 \%$, menunjukkan peningkatan sebesar $2,6 \%$ dari tahun $2007^{2}$. Angka tersebut akan semakin meningkat seiring dengan terjadinya transisi demografi yang diikuti juga dengan terjadinya transisi epidemilogi. Bayi yang menderita gizi lebih akan berisiko lebih pula mengalami penyakit degeneratif ketika sudah dewasa $^{3}$. Prevalensi anak balita gizi lebih di Kota Magelang tahun 2012 berdasarkan data di Profil Kesehatan Kota sebesar 5,8\% ${ }^{4}$.

Sebuah penelitian di Semarang menunjukkan bahwa jenis kepadatan MP-ASI yang diberikan sesuai umur berhubungan erat dengan status gizi. ${ }^{5}$ Selain itu pada penelitian yang sama juga ditunjukkan bahwa ada hubungan antara frekuensi pemberian MP-ASI dengan status gizi ${ }^{6}$. Penelitian yang dilakukan Simanjuntak (2007) menunjukkan bahwa di Kabupaten Simalungun tahun 2007, dari 43 responden, pola pemberian ASI dengan kategori baik yaitu pola pemberian MP-ASI yang sesuai tidak dijumpai, kategori kurang baik sebanyak 7 orang $(16,68 \%)$ sedangkan kategori tidak baik sebanyak 36 orang $(83,72 \%)$. Hal tersebut menunjukkan bahwa terdapat ibu yang memberikan MP-ASI sebelum bayi berusia enam bulan $^{7}$.

Briawan dalam penelitiannya membuktikan, bahwa faktor pendukung keberhasilan pemberian ASI eksklusif sampai umur 6 bulan adalah adanya motivasi ibu untuk menyusui. Sedangkan faktor penghambat keberlanjutan pemberian ASI adalah keyakinan ibu bahwa bayi tidak akan cukup memperoleh zat gizi jika hanya diberi ASI sampai umur 6 bulan dan kepercayaan akan susu formula. Penelitian ini membuktikan adanya hubungan antara pengetahuan dan sikap ibu tentang ASI, begitu juga antara praktek pemberian ASI dengan keberlanjutan pemberian ASI eksklusif. Pemberian makanan pendamping ASI yang diberikan pada bayi kurang dari 4 bulan dengan frekuensi yang tinggi yaitu setiap 3-5 jam sekali menyebabkan kenaikan berat badan yang terlalu cepat sehingga mengarah ke gizi lebih. Pemberian ASI dan MP-
ASI yang dilaksanakan dengan baik, tentu akan menimbulkan dampak positif terhadap pertumbuhan dan perkembangan anak di usia balita $^{3}$.

Berdasarkan latar balakang diatas, peneliti tertarik untuk melakukan penelitian terhadap hubungan antara pemberian MP-ASI dengan kejadian status gizi lebih pada bayi usia 6-12 bulan di Kota Magelang. Diharapkan dengan data yang didapat pada penelitian ini bisa menjadi pertimbangan stakeholder untuk membuat program tertentu terkait MP-ASI yang tepat di Kota Magelang.

\section{METODE}

Penelitian ini dilaksanakan di wilayah kerja Dinas Kesehatan Kota Magelang. Pengambilan data dilaksanakan pada bulan Nopember 2013. Ruang lingkup penelitian ini termasuk dalam penelitian bidang gizi masyarakat dan merupakan penelitian observasional dengan desain case control. Populasi kasus pada penelitian ini adalah bayi dengan status gizi lebih usia 6-12 bulan di wilayah kerja Dinas Kesehatan Kota Magelang. Populasi kontrol pada penelitian ini adalah bayi dengan status gizi normal usia 6-12 bulan di wilayah kerja Dinas Kesehatan Kota Magelang. Wilayah penelitian ditentukan berdasarkan tingginya angka prevalensi gizi lebih pada bayi usia 6-12 bulan di Kota Magelang, maka dipilih 4 wilayah yaitu Kelurahan Tidar Krajan, Jambon Tengah, Tuguran, dan Jagoan. Prevalensi gizi lebih untuk masing-masing kelurahan adalah $8,5 \%, 8,2 \%, 9 \%$, dan $9,3 \%$. Selanjutnya, masing-masing dari desa, dipilih beberapa posyandu untuk mengetahui ada/tidaknya bayi usia 6-12 bulan yang gizi lebih dan tinggal di wilayah tersebut. Di Kelurahan Tidar Krajan terdapat 12 subjek, Jambon Tengah terdapat 12 subjek, Tuguran terdapat 14 subjek, dan Jagoan terdapat 16 subjek. Subjek sejumlah 27 anak untuk masingmasing kelompok dengan kriteria bayi gizi lebih berusia 6-12 bulan dengan indeks z-score $\mathrm{BB} / \mathrm{PB}$ > 2 SD sebagai kasus dan bayi berusia 6-12 bulan dengan indeks $\mathrm{z}$-score $-2<\mathrm{BB} / \mathrm{PB} \leq 2 \mathrm{SD}$ sebagai kontrol. Pemilihan subjek penelitian dilakukan dengan menggunakan teknik random sampling yaitu semua balita yang tercatat di posyandu dan memenuhi kriteria, dimasukkan dalam penelitian kemudian diacak sehingga didapatkan jumlah subjek sesuai perhitungan sampel. Responden penelitian adalah pengasuh atau ibu bayi. Pemilihan kontrol dilakukan dengan matching by design untuk kelompok umur, jenis kelamin, 
konsumsi susu formula per hari dan tempat tinggal. Proses matching dimulai dengan penemuan subjek sebagai kasus. Misalkan di Kelurahan Tidar Krajan ditemukan 7 kasus, tetapi ada 1 responden yang menolak untuk ikut penelitian karena alasan tertentu, sehingga kasus yang ditemukan hanya 6 dan kemudian diambil data berupa BB, PB, konsumsi susu formula, dan pemberian MP-ASI. Setelah itu dicari kontrolnya di wilayah tersebut dengan umur, jenis kelamin dan konsumsi susu formula yang sama. Proses matching ini juga berlaku untuk kelurahan yang lain.

Variabel independen terdiri dari jenis MPASI, frekuensi pemberian MP-ASI dan waktu pemberian MP-ASI pertama kali. Variabel dependennya yaitu kejadian gizi lebih. Kejadian gizi lebih didefinisikan sebagai ekspresi ketidakseimbangan antara makanan yang dikonsumsi dengan aktivitas yang diukur dengan baby scale dengan $\mathrm{z}$-score $\mathrm{BB} / \mathrm{PB}>+2 \mathrm{SD}$. Jenis MP-ASI adalah jenis makanan yang diberikan sebagai MP-ASI baik cair, saring, lunak, maupun padat yang dikategorikan menjadi 2 besar yaitu sesuai umur dan tidak sesuai umur. Berdasarkan kategori Depkes RI 2007, makanan bayi usia 6-9 bulan adalah bubur susu dan bubur tim, sedangkan usia 9-12 adalah bubur nasi dan nasi lembek. Frekuensi pemberian MP-ASI didefinisikan sebagai jumlah pemberian MP-ASI dalam sehari yang dikategorikan lebih dari 3 kali sehari dan kurang dari sama dengan 3 kali sehari. Sedangkan waktu pemberian MP-ASI pertama kali didefinisikan sebagai usia dimana bayi pertama kali mendapat MP-ASI yang dikategorikan sebelum 6 bulan dan setelah 6 bulan. ${ }^{8}$

Data yang dikumpulkan meliputi identitas subjek, umur, jenis kelamin, berat badan, dan panjang badan. Data variabel independen diperoleh melalui wawancara dengan responden. Data recall juga dilakukan untuk melakukan matching asupan susu, apakah berasal dari susu formula saja, ASI saja, atau gabungan keduanya. Data antropometri berat badan diperoleh dengan menggunakan infant scale yang memiliki ketelitian $0,1 \mathrm{~kg}$. Sedangkan panjang badan menggunakan alat pengukur panjang badan $(<2$ tahun) dengan ketelitian $0,1 \mathrm{~cm}$. Analisis data dilakukan dengan menggunakan program Statistical Package for the Social Science (SPSS) 17. Analisis univariat dilakukan untuk menyajikan data secara deskriptif dengan menggunakan tabel distribusi. Analisis deskriptif dilakukan terhadap umur, jenis kelamin, dan semua variabel. Analisis bivariat dilakukan untuk mengetahui hubungan variabel dependen dan independen dalam bentuk tabulasi silang (crosstab) menggunakan uji chi square. Pada penelitian kasus kontrol dapat diukur besarnya risiko antar variabel dengan menggunakan Odds Ratio (OR). ${ }^{9}$ Odds Ratio (OR) menunjukkan berapa sering terdapat pajanan pada kelompok kasus dibandingkan pada kelompok kontrol. Odds Ratio dihitung menggunakan tabel $2 \times 2$.

\section{HASIL PENELITIAN \\ Karakteristik Subjek}

Jumlah subjek dalam penelitian ini sebanyak 54 anak balita yang terdiri dari 27 bayi gizi lebih dan 27 bayi gizi normal. Secara keseluruhan sebanyak 59,3\% subjek berjenis kelamin perempuan, dan $49,7 \%$ subjek berjenis kelamin laki-laki. Konsumsi rata-rata susu formula per hari untuk semua subjek sebesar 2,3 $\pm 0,7$ kali. Tabel 1 menunjukkan rerata z-score kelompok

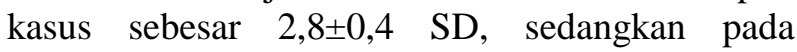
kelompok kontrol reratanya sebesar $0,04 \pm 1,2 \mathrm{SD}$. Rerata frekuensi pemberian MP-ASI pada kelompok kasus dalam sehari sebesar 4,7 $\pm 0,8$ kali per hari, sedangkan pada kelompok kontrol 3,7 $\pm 0,6$ kali per hari. Rerata kelompok kasus mendapat MP-ASI pertama kali pada usia 2,3 $\pm 0,7$ bulan sedangkan pada kelompok kontrol pada usia $6,04 \pm 0,9$ bulan.

Tabel 1. Deskripsi umum karakteristik subjek

\begin{tabular}{lcc}
\hline \multicolumn{1}{c}{ Gambaran Umum } & $\begin{array}{c}\text { Bayi gizi lebih } \\
(\mathbf{n = 2 7})\end{array}$ & $\begin{array}{c}\text { Bayi gizi normal } \\
(\mathbf{n = 2 7})\end{array}$ \\
\hline Z-score BB/PB (SD) & $2,8 \pm 0,4$ & $0,04 \pm 1,2$ \\
& $2,1-3,9$ & $-1,8-1,8$ \\
Frekuensi pemberian MP-ASI (kali/hari) & $4,7 \pm 0,8$ & $3,7 \pm 0,6$ \\
& $3-6$ & $3-5$ \\
Waktu pertama kali pemberian & $4,6 \pm 1,5$ & $6,04 \pm 0,9$ \\
(bulan) & $2-7$ & $4-7$ \\
Konsumsi susu formula (kali/hari) & $2,3 \pm 0,7$ & $2,3 \pm 0,7$ \\
& $1-3$ & $1-3$ \\
\hline
\end{tabular}




\section{Kejadian Gizi Lebih}

Tabel 2. Tabel silang jenis MP-ASI, frekuensi pemberian MP-ASI, dan waktu pemberian MP-ASI pertama kali dengan kejadian gizi lebih

\begin{tabular}{|c|c|c|c|c|c|c|}
\hline & \multicolumn{4}{|c|}{$\begin{array}{c}\text { Status gizi berdasarkan } z \text {-score } \\
\mathrm{BB} / \mathrm{PB}\end{array}$} & \multirow[t]{3}{*}{$\mathbf{P}$} & \multirow[t]{3}{*}{ OR (CI 95\%) } \\
\hline & \multicolumn{2}{|c|}{ Gizi lebih } & \multicolumn{2}{|c|}{ Normal } & & \\
\hline & $\mathbf{n}$ & $\%$ & $\mathbf{N}$ & $\%$ & & \\
\hline \multicolumn{7}{|l|}{ Jenis MP-ASI } \\
\hline Tidak sesuai umur & 15 & 55,6 & 11 & 40,7 & 0,4 & 1,8 \\
\hline Sesuai umur & 12 & 44,4 & 16 & 59,3 & & $0,6-5,3$ \\
\hline \multicolumn{7}{|c|}{$\begin{array}{l}\text { Frekuensi pemberia } \\
\text { MP-ASI }\end{array}$} \\
\hline >3 kali/hari & 26 & 96,3 & 16 & 59,3 & 0,002 & 17,9 \\
\hline$\leq 3 \mathrm{kali} / \mathrm{hari}$ & 1 & 3,7 & 11 & 40,7 & & $2,1-151,9$ \\
\hline \multicolumn{7}{|l|}{$\begin{array}{l}\text { Waktu pemberian } \\
\text { MP-ASI }\end{array}$} \\
\hline Sebelum 6 bulan & 18 & 66,7 & 8 & 29,6 & 0,01 & 4,8 \\
\hline Setelah 6 bulan & 9 & 33,3 & 19 & 70,4 & & $1,5-15$ \\
\hline
\end{tabular}

\section{PEMBAHASAN}

Berdasarkan tabel $1, \quad \mathrm{z}$-score pada kelompok kasus dengan rerata 2,8 $8 \pm 0,4$ SD sedangkan kelompok kontrol $0,04 \pm 1,2$ SD. Jelas terlihat perbedaan yang mencolok, kelompok kasus pada kategori gizi lebih sedangkan kelompok kontrol pada kategori gizi normal. Rerata jenis MP-ASI yang dikonsumsi kelompok kasus adalah bubur nasi, sedangkan pada kelompok kontrol bubur tim. Frekuensi pemberian MP-ASI kelompok kasus per hari sebanyak 4,7 $\pm 0,8$ kali

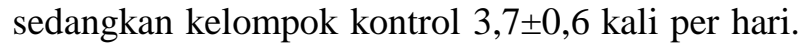
Rerata keduanya diatas 3 kali per hari tetapi pada kelompok kontrol tidak sampai 4 kali per hari karena ada 59,3\% subjek yang mengonsumsi lebih dari 3 kali per hari sedangkan kelompok kasus 96,3\% mengonsumsi MP-ASI lebih dari 3 kali per hari. Waktu pemberian MP-ASI pertama kali pada kelompok kasus dengan rerata umur 4,6 $\pm 1,5$ bulan sedangkan pada kelompok kontrol pada usia $6,04 \pm 0,9$ bulan. Terlihat perbedaan bahwa pada kelompok kasus pemberian MP-ASI lebih dini dibandingkan dengan kelompok kontrol. Konsumsi susu formula pada kedua kelompok dengan rerata 2,3 $\pm 0,7$ kali per hari. Frekuensi konsumsi susu formula pada kedua kelompok per hari paling tinggi sebanyak 3 kali per hari dan tersebar pada umur 7-12 bulan.

Berdasarkan tabel 2, pada kelompok kasus, pemberian MP-ASI yang tidak sesuai umur sebesar 57,7\% sedangkan pada kelompok kontrol sebesar $55,6 \%$. Selisih keduanya tidak terlalu jauh sehingga secara statistik pun juga pemberian MPASI yang tidak sesuai umur bukan merupakan faktor risiko gizi lebih $(\mathrm{p}=0,4)$. Pada kelompok kasus, frekuensi pemberian MP-ASI pada kategori lebih dari 3 kali per hari sebesar 96,3\% sedangkan kelompok kontrol sebesar 59,3\%. Terlihat perbedaan yang mencolok pada kedua kelompok sehingga secara statistik, frekuensi pemberian MPASI merupakan faktor risiko gizi lebih $(\mathrm{p}=0,002)$. Pada kelompok kasus, subjek yang mendapat MPASI sebelum usia 6 bulan sebesar $66,7 \%$ sedangkan pada kelompok kontrol sebesar 29,6\% saja. Terlihat perbedaan yang mencolok pada kedua kelompok sehingga secara statistik, waktu pemberian MP-ASI sebelum usia 6 bulan merupakan faktor risiko terjadinya gizi lebih $(\mathrm{p}=0,01)$.

Berdasarkan teori wanita memiliki jumlah lemak tubuh lebih banyak dibandingkan laki-laki, subjek dalam penelitian ini juga menunjukkan hal yang sejalan dengan teori tersebut. Sebanyak $59,3 \%$ subjek adalah perempuan. Selain itu, anak laki-laki memiliki aktivitas lebih banyak walaupun mereka masih bayi dan cenderung lebih aktif. Ada beberapa sebab yang membuat ibu atau pengasuh bayi untuk memberikan susu formula sebelum waktunya. Hal ini akan menjadi salah satu penyebab gizi lebih pada bayi. Walaupun dalam penelitian ini tidak dilakukan uji hubungan, tetapi dilakukan wawancara sehingga diketahui berapa kali bayi mendapat susu formula dalam sehari dan itu merupakan unsur matching yang dilakukan 
dalam penelitian ini. Secara keseluruhan rerata konsumsi susu formula perhari sebesar 2,3 $\pm 0,7$ kali per hari dan ditambah wawancara singkat susu formula yang dikonsumsi dengan menggunakan dot kecil untuk usia 6-8 bulan dan dot sedang untuk usia 9-12 bulan.

Pada kelompok kasus, sebagian besar subjek mengonsumsi bubur nasi $(48,1 \%)$, sedangkan kelompok kontrol mengonsumsi bubur tim $(44,4 \%)$. Hasil penelitian ini menunjukkan bahwa pemberian MP-ASI yang tidak sesuai umur bukan merupakan faktor risiko terjadinya gizi lebih pada bayi usia $6-12$ bulan $(\mathrm{p}=0,4 ; \mathrm{OR}=0,55 ; 95 \% \mathrm{CI}$ : 0,19-1,6). Penelitian ini sejalan dengan penelitian pada etnis Banjar yang menunjukkan bahwa sebagian besar subjek usia 6-12 bulan yang mengonsumsi MP-ASI yang sesuai umurnya memiliki status gizi normal. Tidak ada angka signifikan pada penelitian ini karena merupakan studi kualitatif. ${ }^{5}$ MP-ASI yang diberikan pada anak harus bertahap kepadatannya disesuaikan dengan perkembangan umurnya sebab hal ini disesuaikan dengan keadaan fisiologis bayi. ${ }^{7}$ Jenis makanan yang cocok untuk bayi usia 0-6 bulan hanyalah ASI. Pemberian makanan tambahan pada anak usia dini yang tidak sesuai umurnya bisa menyebabkan beberapa akibat, diantaranya infeksi, kenaikan berat badan (obesitas), dan alergi terhadap makanan tertentu. MP-ASI harus diberikan sesuai umurnya, misalnya anak usia 6 bulan yang sudah diberikan nasi lembek, hal ini tidak sesuai karena MP-ASI yang sesuai adalah bubur susu. Akibat yang ditimbulkan karena pemberian MP-ASI tidak sesuai umur meliputi jangka pendek dan jangka panjang. Akibat jangka pendek yang timbulkan adalah infeksi saluran pencernaan dan kekurangan gizi. Sedangkan akibat jangka panjang yang timbul adalah obesitas karena asupan energi yang berlebih dan bahkan bayi akan membawa kebiasaan tersebut sampai dewasa. Lambung yang sudah terbiasa mendapat asupan energi berlebih akan terasa kurang apabila yang dimakan hanya sekedar mencukupi kebutuhan harian. ${ }^{8}$ Secara teori, ketidaksesuaian MP-ASI yang diberikan merupakan faktor risiko terjadinya gizi lebih, tetapi subjek pada penelitian ini baik kelompok kasus maupun kelompok kontrol, persentase yang mengonsumsi jenis MP-ASI tidak sesuai umur, jumlahnya hampir sama sehingga tidak ada hubungan yang signifikan antara pemberian MPASI yang tidak sesuai umur dengan kejadian gizi lebih.

Hasil penelitian ini juga menunjukkan bahwa frekuensi pemberian MP-ASI dalam sehari merupakan faktor risiko terjadinya gizi lebih pada bayi usia $6-12$ bulan $(\mathrm{p}=0,002$; OR=17,9 $(95 \% \mathrm{CI}$ 2,1-151,9). Hasil penelitian ini sejalan dengan penelitian di Surabaya yang menunjukkan bahwa ada hubungan yang signifikan antara frekuensi pemberian makanan pendamping ASI dengan status gizi anak usia 6-23 bulan. ${ }^{10}$ Hasil penelitian ini juga menunjukkan bahwa rerata frekuensi pemberian MP-ASI pada kelompok kasus per hari sebesar 4,7 kali per hari dimana jumlahnya lebih sering dibandingkan kelompok kontrol dengan rerata 3,7 kali per hari. Sebenarnya dari kedua kelompok, frekuensi pemberian MP-ASI tidak sesuai dengan standar yang sudah ditetapkan bahwa frekuensi pemberian MP-ASI hanya 3 kali per hari. Ketidaksesuaian ini terjadi karena ibu tidak membuat jadwal pemberian MP-ASI yang baik menurut kebutuhan bayinya. Pengaruh frekuensi dalam pemberian MP-ASI yaitu jika frekuensi pemberian kurang akan berakibat kebutuhan gizi anak tidak terpenuhi, dan jika berlebihan akan mengakibatkan bayi mendapatkan zat gizi yang berlebihan. Menurut Depkes-RI (2006), kurangnya frekuensi pemberian MP-ASI dalam sehari akan berakibat gizi anak tidak terpenuhi, dan pemberian MP-ASI yang melebihi frekuensi pemberian akan mengarah pada gizi lebih. ${ }^{11}$

Pada anak usia 6-12 bulan, selain ASI, bayi mulai bisa diberi makanan pendamping ASI, karena pada usia itu bayi sudah mempunyai refleks mengunyah dengan pencernaan yang lebih kuat. Dalam pemberian makanan bayi perlu diperhatikan ketepatan waktu pemberian, frekuensi, jenis, jumlah bahan makanan, dan cara pembuatannya. ${ }^{12}$ Hasil penelitian ini menunjukkan bahwa waktu pemberian MP-ASI pertama kali merupakan faktor risiko gizi lebih $(\mathrm{p}=0,01)$ dengan rerata waktu pemberian MP-ASI pada kelompok kasus lebih dini dibandingkan dengan kelompok kontrol yaitu $4,6 \pm 1,5$ bulan, sedangkan pada kelompok kontrol, rerata usia pemberian MP-ASI pertama kali sudah sesuai yaitu $6,04 \pm 0,9$. Penelitian ini sejalan dengan penelitian di Yogyakarta yang menunjukkan ada hubungan antara pola pemberian MP-ASI dengan peningkatan status gizi pada bayi usia 6-24 bulan. ${ }^{13}$ Pemberian MP-ASI yang terlalu dini selain berakibat gizi lebih juga bisa menimbulkan beban zat terlarut hingga dapat menimbulkan hyperosmolarity (kelebihan tekanan osmotik pada plasma sel karena adanya peningkatan konsentrasi zat), kenaikkan berat badan yang terlalu cepat dapat menyebabkan gizi lebih, alergi terhadap salah satu zat gizi yang terdapat dalam makanan 
yang diberikan pada bayi. Bayi yang mendapat zatzat tambahan seperti garam dan nitrat dapat merugikan ginjal bayi yang belum matang, dalam makanan padat yang dipasarkan terdapat zat pewarna atau zat pengawet yang membahayakan dalam penyediaan dan penyimpanan makanan ${ }^{1}$.

Makanan yang sesuai untuk bayi usia 0-6 bulan adalah ASI. Sesuai yang dimaksud adalah sesuai jumlah energi dan teksturnya. Pemberian MP-ASI dibawah usia 6 bulan menyebabkan bayi mendapat energi lebih banyak dari yang dibutuhkan. Bayi memiliki daya tahan tubuh yang berbeda-beda. Bayi yang memiliki daya tahan tubuh kurang apabila mendapat MP-ASI sebelum usia 6 bulan akan berpeluang terkena infeksi yang mengarah pada gizi kurang. Sedangkan pada bayi yang memiliki daya tahan tubuh tinggi, pemberian MP-ASI pada usia sebelum 6 bulan akan berpeluang menjadi gizi lebih. Pemberian MP-ASI sebelum usia 6 bulan sering dihubungkan dengan meningkatnya kandungan lemak dan berat badan. Karena itulah, menunda pemberian MP-ASI sampai usia 6 bulan dapat melindunginya dari gizi lebih di kemudian hari. Beberapa enzim pemecah protein seperti pepsin, lipase, dan amilase, serta asam lambung, baru akan diproduksi sempurna pada saat bayi berusia 6 bulan. ${ }^{14}$ Sebuah studi di Amerika mengungkapkan bayi yang mendapatkan makanan padat sebelum usia 4 bulan cenderung menjadi lebih gemuk. Salah satu penulis studi ini dari Children's Hospitas Boston mengatakan, mengikuti pedoman yang benar dapat mengurangi risiko gizi lebih pada masa kanak-kanak. ${ }^{15}$

Gizi lebih merupakan salah satu gangguan status gizi yang bisa berakibat fatal di masa mendatang. Trend penyakit di Indonesia sudah mulai bertambah menjadi gizi lebih dan gizi kurang yang sering disebut "double burden". Penyakit ini merupakan penyakit tidak menular tetapi seiring dengan berkembangnya jaman kearah modern justru menjadi penyakit menular melalui gaya hidup. Sering dijumpai di masyarakat bahwa bayi yang gemuk adalah bayi yang sehat. Stigma seperti ini harus segera dihilangkan karena gizi lebih sejak dini justru lebih bahaya karena jika status gizi bayi sampai dewasa dalam kategori lebih akan sulit diturunkan dan menjadi pemicu lahirnya berbagai penyakit degeneratif. ${ }^{16}$

Tujuan pemberian makanan pendamping ASI adalah untuk menambah energi dan zat-zat gizi yang diperlukan bayi karena ASI tidak dapat memenuhi kebutuhan bayi secara terus menerus. Selain itu agar bayi mencapai pertumbuhan perkembangan yang optimal dan menghindari terjadinya kekurangan gizi, defesiensi zat gizi mikro (zat besi, zink, kalsium, vitamin A, vitamin C dan folat), menyediakan makanan ekstra yang dibutuhkan untuk mengisi kesenjangan energi dengan nutrisi. Dipandang dari segi kekebalan, pemberian MP-ASI dapat memelihara kesehatan, mencegah penyakit, memulihkan bila sakit, membantu perkembangan jasmani, rohani, psikomotor, mendidik kebiasaan yang baik tentang makanan dan memperkenalkan bermacam-macam bahan makanan yang sesuai dengan keadaan fisiologis bayi. ${ }^{17}$ Akan tetapi apabila pola pemberiannya tidak sesuai dengan persyaratan kesehatan yang sudah ditetapkan, maka berakibat malnutrisi dan salah satunya gizi lebih.

\section{KESIMPULAN}

Faktor risiko kejadian gizi lebih pada bayi usia 612 bulan di Kota Magelang adalah frekuensi pemberian MP-ASI dan waktu pertama kali pemberian MP-ASI.

\section{DAFTAR PUSTAKA}

1. Fryar CD, Carroll MD, Ogden CL. Prevalence of Obesity Among Children and Adolescents : United States, Trends 1963-1965 Through 2009-2010. NCHS Health States. September 2012

2. Badan Penelitian dan Pengembangan Kesehatan Kementrian Kesehatan RI. Riset Kesehatan Dasar 2010. Laporan Nasional 2010. http://www.riskesdas.litbang.depkes.go.id

3. Yusriani, Siti Fatimah, Citrakesumasari. Beberapa Faktor Risiko yang Mempengaruhi Kejadian Gizi Lebih Pada Balita Usia (24-59 bulan) di Wilayah Kerja Puskesmas Bara-Baraya Kota Makkasar Tahun 2005. Jurnal Kesehatan Masyarakat Madani, 2008;01:1979-2287.

4. Dinas Kesehatan Kota Magelang. Profil Kesehatan Kota Magelang Tahun 2012. Magelang : 2013.

5. Ida Hayati, Suriah, Nur Haedar Jafar. Pola Pemberian MP-ASI Bayi 6-12 Bulan Pada Etnis Banjar di Kelurahan Telung Lerong Ilir. Makkasar: Universitas Hassanudin. 2012.

6. Afiana Rohmani. Pemberian MPASI Pada Anak Usia 1-2 tahun di Kelurahan Lamper Tengah Kecamatan Semarang Selatan Kota Semarang. Prosiding Seminar Nasional UNIMUS. 2010.

7. Mery Susanty, Mesri Kartika, Veni Hadju, Sri'ah Alharini. Hubungan Pola Pemberian ASI dan MPASI dengan Gizi Buruk Pada Anak Usia 6-24 bulan di Kelurahan Pennampu Makassar. Media Gizi Masyarakat Indonesia. 2012;1:97-103.

8. Departemen Kesehatan RI. Pedoman Umum Gizi Seimbang. Jakarta: Departemen Kesehatan RI .2007 
9. Sudigdo S, Sofyan I. Dasar-Dasar Metodologi Klinis. Ed 3. Jakarta: Sagung Seto. 2008. hlm 1279, 139.

10. Solihin Pujiadi. Ilmu Gizi Klinis pada Anak. Jakarta: Fakultas Kedokteran Universitas Indonesia ; 2005. p. 96-137

11. Firdhani E, \& Gunanti I. Pola Pemberian Asi, MPASI dan Status Gizi Anak Usia 1-2 Tahun Pada Keluarga Etnis Madura dan Etnis Arab (Studi Di Puskesmas Pegirian dan Puskesmas Perak Timur Surabaya). Jurnal Pusat Penelitian dan Pengembangan Gizi dan Makanan, Badan Litbang Kesehatan, Kementerian Kesehatan, 2005: 8 (2), hal. 35-41.

12. Gibson RS, Ferguson EL, \& Lehrfeld J. Complementary Foods For Infant Feeding In Developing Countries: Their Nutrient Adequacy And Improvement. European Journal of Clinical Nutrition, 2008 ; 72, p. 421-429

13. Septiana R, Djannah RSN, Djamil MD. Hubunga Antara Pola Pemberian MP-ASI dengan Status Gizi Bayi Usia 6-24 bulan di Wilayah Kerja Kecamatan Gedongtengen Yogyakarta. Jurnal KESMAS UAD, $2009 ; 118$

14. Stallings VA, Fung EB. Clinical Nutrition Assessment of Infants and Children. In: Shils M, Olson JA, Shike M, Ross AC, editors. Modern Nutrition in Health and Disease. 9th ed. Baltimore: Williams \& Wilkins; 1999. p. 567.

15. Onis Md, Onyango AW, Borghi E, Garza C, Yang H. Comparison of the World Health Organization (Who) Child Growth Standards and The National Center For Health Statistics/WHO International Growth Reference: Implication For Child Healith Programmes. Public Health Nutrition. 2006; 9: 942-7.

16. Subardja D. Obesitas Primer Pada Anak, Cetakan I, Penerbit PT. Kiblat Buku Utama, Jakarta, 2004.

17. Baisden B, Bunyapen C, Bhatia J. Feeding The Premature Infant. In: Berdanier CD, Dwyer J, Feldman EB, editors. Handbook of Nutrition and Food. 2nd ed. New York: CRC press; 2008. p. 79, 236, 259, 281. 